\title{
Spatial and Temporal Variability of Dissolved Sulfate in Devils Lake, North Dakota, 1998
}

\section{Introduction}

The Devils Lake Basin is a 3,810-squaremile closed subbasin of the Red River of the North Basin (fig. 1). About 3,320 square miles of the total 3,810 square miles is tributary to Devils Lake. The Devils Lake Basin contributes to the Red River of the North Basin when the level of Devils Lake is greater than 1,459 feet above sea level.

Lake levels of Devils Lake were recorded sporadically from 1867 to 1890 . In 1901, the U.S. Geological Survey established a gaging station on Devils Lake. From 1867 through 1998 , the lake level has fluctuated between a minimum of $1,400.9$ feet above sea level in 1940 and a maximum of 1,444.7 feet above sea level in 1998 (fig. 2). The maximum, which occurred on July 7. 1998, was 22.1 feet higher than the level recorded in February 1993.

The rapid rise in the lake level of Devils Lake since 1993 is in response to abovenormal precipitation and below-normal evaporation from the summer of 1993 through 1998. Because of the rising lake level, more than 50,000 acres of land and many roads around the lake have been flooded. In addition, the water quality of Devils Lake changed substantially in 1993 because of the summer flooding (Williams-Sether and others, 1996). In response to the flooding, the Devils Lake Basin Interagency Task Force, comprised of many State and Federal agencies, was formed in 1995 to find and propose intermediate ( 5 years or less) flood mitigation options. Current and accurate hydrologic and water-quality information is needed to assess the effectiveness of the flood mitigation options, which include managing and storing water in the Devils Lake Basin, continuing infrastructure protection, and providing an outlet to the Sheyenne River (Wiche, 1998).

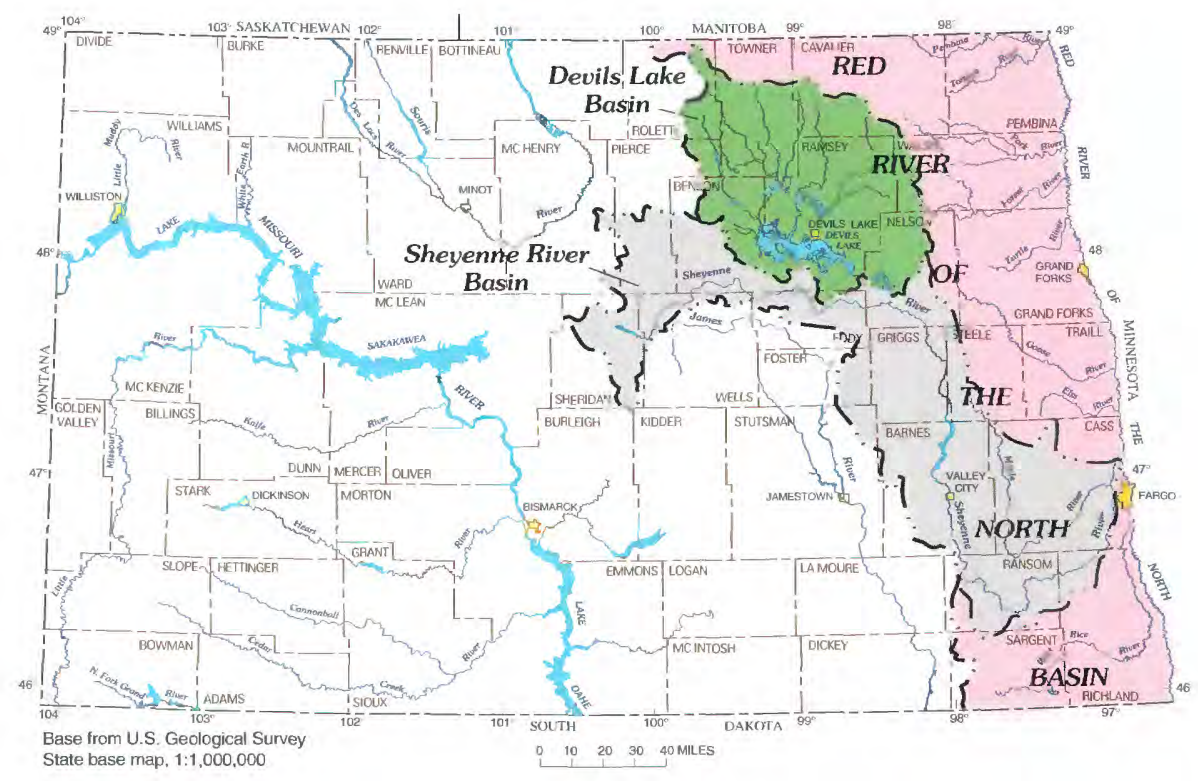

Figure 1. Location of the Devils Lake Basin.

As part of the U.S. Army Corps of Engineers Devils Lake emergency outlet feasibility study, the U.S. Geological Survey is modeling lake levels and sulfate concentrations in Devils Lake to simulate operation of an emergency outlet.

Accurate simulation of sulfate concentrations in Devils Lake is required to determine potential effects of the outlet on downstream water quality. Historical sulfate concentrations are used to calibrate and verify the model. Most of the Devils Lake water-quality data available before 1998 were obtained from samples collected from the water column about three to four times a year. The samples were collected at one location in each of the Devils Lake major bays (West Bay, Main Bay, East Bay, and East Devils Lake). However, sample collection from only one location in a bay may not give an adequate representation of the water quality of the bay because of factors such as wind, precipitation, temperature, surface- and ground-water inflow, and possible bed-sediment interactions. Thus, spatial variability (the variability within each bay) and temporal variability (the variability with time) of dissolved sulfate need to be determined to evaluate the accuracy of the estimates obtained from the model.

\section{Water-Quality Sampling}

Spatial and temporal sampling schedules were created to address the variability of dissolved-sulfate concentrations in the Devils Lake major bays between May and August 1998. Samples were collected from 30 sites in Devils Lake (fig. 3). Of the 30 sites, 9 are historical sample sites and the remaining are distributed across the bays to represent about the same volume of water. Accurate determination of site locations was obtained using a Global Positioning System receiver.

The spatial sampling schedule was designed to determine water-quality variability within each bay once during the spring lake-level rise (May 4 and 5) 


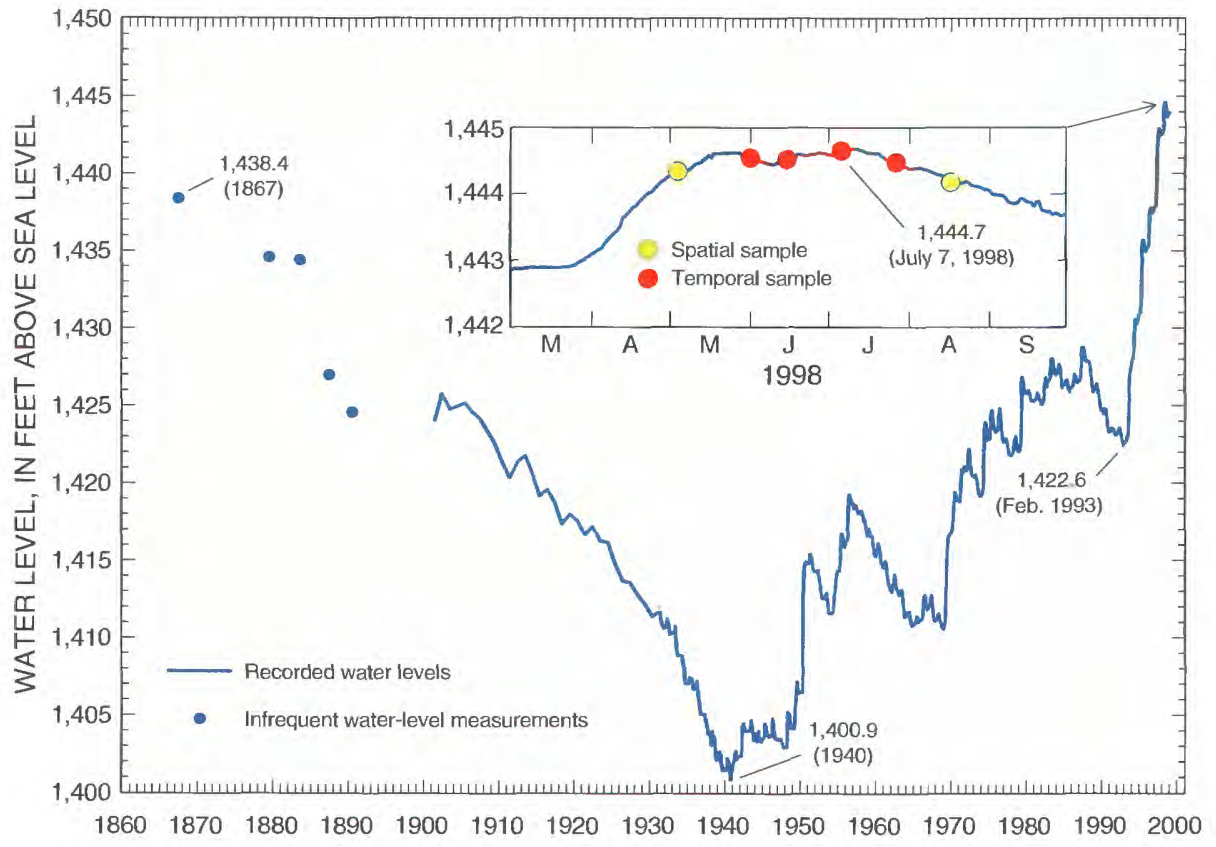

Figure 2. Historical water level for Devils Lake, 1867-1998, and sample collection times in 1998.

and once during the summer lake-level decline (August 17 and 18) (fig. 2).

During both sampling periods, a water sample and a water-column profile were collected at each of the 30 sites (fig. 3).

The temporal sampling schedule was designed to determine water-quality variability with time between the two spatial sampling periods. On June $I$ and 2 , June 15 and 16, July 6 and 7, and July 27 and 28 , a water sample and a watercolumn profile were collected at each of nine sites (the temporal sample sites, fig. 3), and a water-column profile was collected at seven additional sites (the temporal profile sites, fig. 3 ).

Water samples were collected from the surface, middle, and bottom of the water column and composited in a churn splitter. Water samples then were taken from the churn splitter and analyzed at the North Dakota Department of Health Laboratory in Bismarck, N. Dak., for the constituents listed in table 1. Dissolved sulfate is the only constituent discussed in this fact sheet. The remaining constituents are listed to indicate other data available from this study. Water-column profiles consisted of measurements of specific conductance, $\mathrm{pH}$, water temperature, and dissolved oxygen at various depths from the surface to the bottom of the water column. Air temperature, barometric pressure, wind direction, windspeed, and secchi-disk transparency also were measured.

\section{Spatial Variability of Dissolved Sulfate}

Dissolved-sulfate concentrations at spatial sample sites increased abruptly from west to east near the boundaries between bays (fig, 4). However, variability within the bays is much smaller than variability between the bays. The concentrations in West Bay and Main Bay are particularly homogeneous because of efficient winddriven mixing in those bays. Thus, the concentration of a single sample from the Department of Health Laboratory historical sample site for West Bay (site 9) or Main Bay (site 18) accurately represents the average dissolved-sulfate concentration in each of those bays during both the spring and summer sampling periods.

The greater spatial variability of dissolved-sulfate concentrations in East Bay and East Devils Lake, particularly in the spring, indicates wind-driven mixing in those bays is not as complete as in West Bay and Main Bay. The concentrations in samples collected on May 4 and 5 from the historical sample sites for East Bay (site 25) and East Devils Lake (site 29) are less than the average concentrations in East Bay and East Devils Lake. However, the concentrations in samples collected on August 17 and 18 are more homogeneous and more accurately represent the average dissolved-sulfate concentration in each of those bays.

The abrupt changes in concentration between bays indicate mixing between bays is much less efficient than mixing within bays. Constrictions at Ziebach Pass (West Bay - Main Bay), Highway 20 (Main Bay - East Bay), and WoodsRutten Road (East Bay - East Devils Lake) generally hinder the mixing between bays. However, mixing between West Bay and Main Bay is enhanced because of the high lake levels during the sampling periods. This mixing is particularly evident in the summer, as indicated by the relatively smooth transition between West Bay and Main Bay concen-

Table 1. Constituents for which water samples were analyzed at the North Dakota

\begin{tabular}{llll}
\hline Major cations/anions & Trace metals & \multicolumn{1}{c}{ Nutrients } & Chlorophyll \\
\hline Calcium. dissolved & Aluminum & Nitrite plus nitrate & Chlorophyll a \\
Magnesium. dissolved & Antimony & Ammonia & Chlorophyll b \\
Sodium, dissolved & Arsenic & Organic nitrogen & \\
Potassium, dissolved & Barium & Total nitrogen & \\
Alkalinity, dissolved & Beryllium & Total phosphorus & \\
Sulfate, dissolved & Boron & Dissolved phosphorus & \\
Chloride, dissolved & Cadmium & & \\
Dissolved solids & Chromium & & \\
& Copper & & \\
& Iron & & \\
& Lead & & \\
& Manganese & & \\
& Nickel & & \\
& Selenium & & \\
& Silver & & \\
& Thallium & \\
& Zinc & \\
& &
\end{tabular}




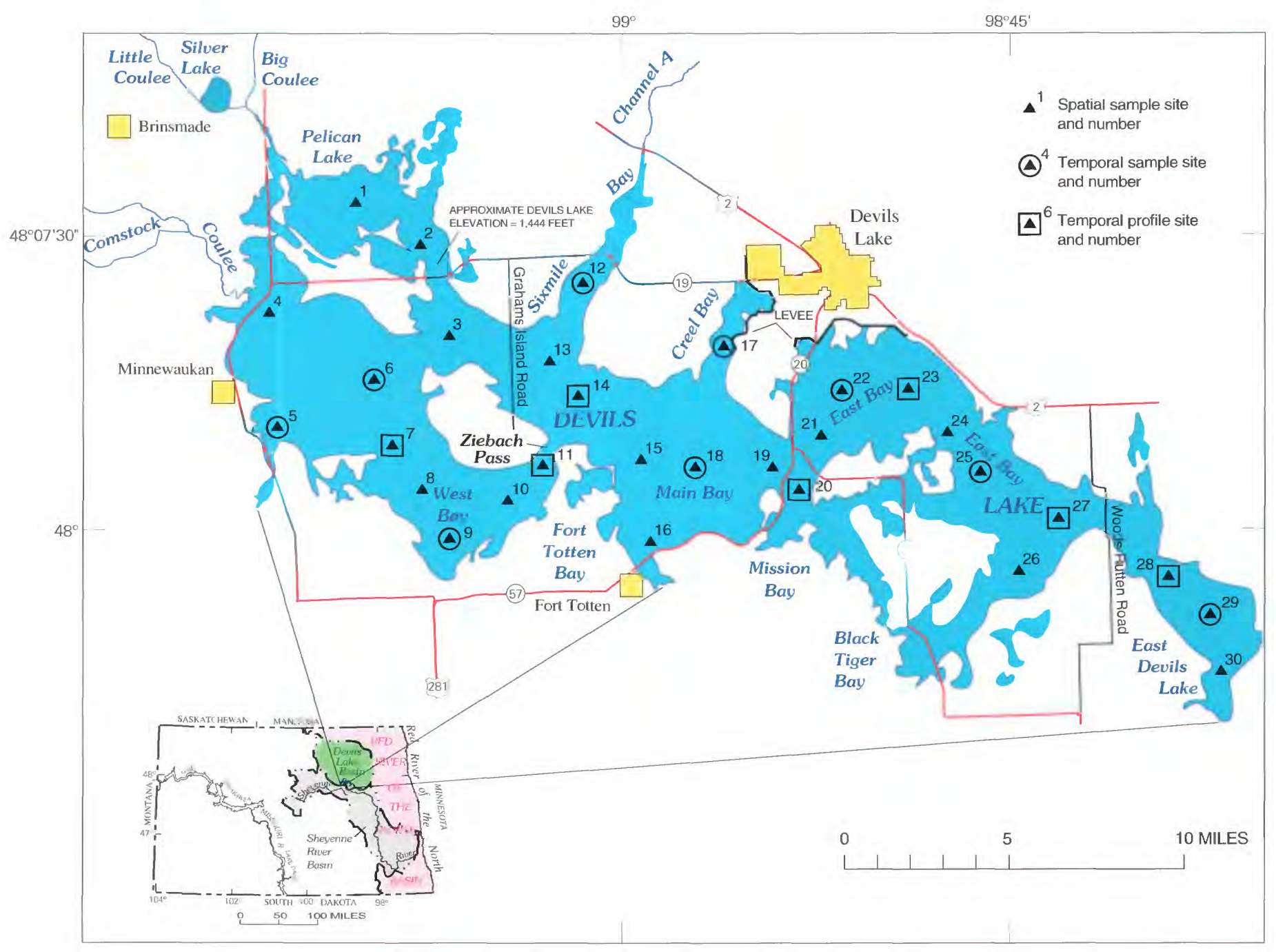

Figure 3. Locations of sample sites in Devils Lake.

trations (fig. 4). The more abrupt change in the spring is caused by flow from West Bay to Main Bay reducing the amount of mixing that occurs between the bays.

Mixing between Main Bay and East Bay is greatly restricted by a small bridge opening at Highway 20. Thus, dissolvedsulfate concentrations are much larger in East Bay than in Main Bay. The difference between dissolved-sulfate concentrations in Main Bay and East Bay is about the same in the summer as in the spring, indicating that mixing is hindered even in the summer when lake levels are declining.

Woods-Rutten Road, which separates East Bay and East Devils Lake, was overtopped during 1998, allowing considerable mixing between those bays. During the spring lake-level rise, water flowed from East Bay to East Devils Lake, causing sulfate dilution in East Devils Lake. However, the increased concentration in East Bay in the summer indicates water from East Devils Lake mixed with water from East Bay. In the fall of 1998 ,

Woods-Rutten Road was raised, and East Bay again was separated from East Devils Lake.

\section{Temporal Variability of Dissolved Sulfate}

Trends in dissolved-sulfate concentrations at temporal sample sites varied between bays (fig. 5). Concentrations at site 5 in West Bay decreased from May 5 to June I when inflow from Big Coulee slowly diluted water in West Bay. From June 1 through August 17, concentrations increased as a result of evaporation, mixing within West Bay, and possible flux of sulfate from bed sediment. Concentrations at site 9 increased from May 5 to June 1, indicating that flux of sulfate from bed sediment and/or mixing with Main Bay were sufficient to counteract dilution from inflow during the spring lake-level rise. Concentrations decreased from June 1 to 15 and then slowly increased to 520 milligrams per liter $(\mathrm{mg} / \mathrm{L})$ on August 17. Although concentrations at site 5 and site 9 began to converge in July and August, the concentrations at site 5 were less than the concentrations at site 9 during the entire sampling period. Thus, although the concentrations in West Bay are relatively homogeneous, small differences occur among sites and persist well into late summer.

Dissolved-sulfate concentrations at site 18 in Main Bay steadily decreased from $660 \mathrm{mg} / \mathrm{L}$ on May 5 to $600 \mathrm{mg} / \mathrm{L}$ on July 27 and then increased to $620 \mathrm{mg} / \mathrm{L}$ on August 17. The decrease indicates that dilution from Channel $\mathrm{A}$ and West Bay was sufficient to counteract the flux of sulfate from bed sediment and/or mixing with East Devils Lake during the spring lake-level rise. However, in late summer, concentrations increased as inflow decreased and evaporation increased.

Dissolved-sulfate concentrations at site 25 in East Bay increased during the entire 


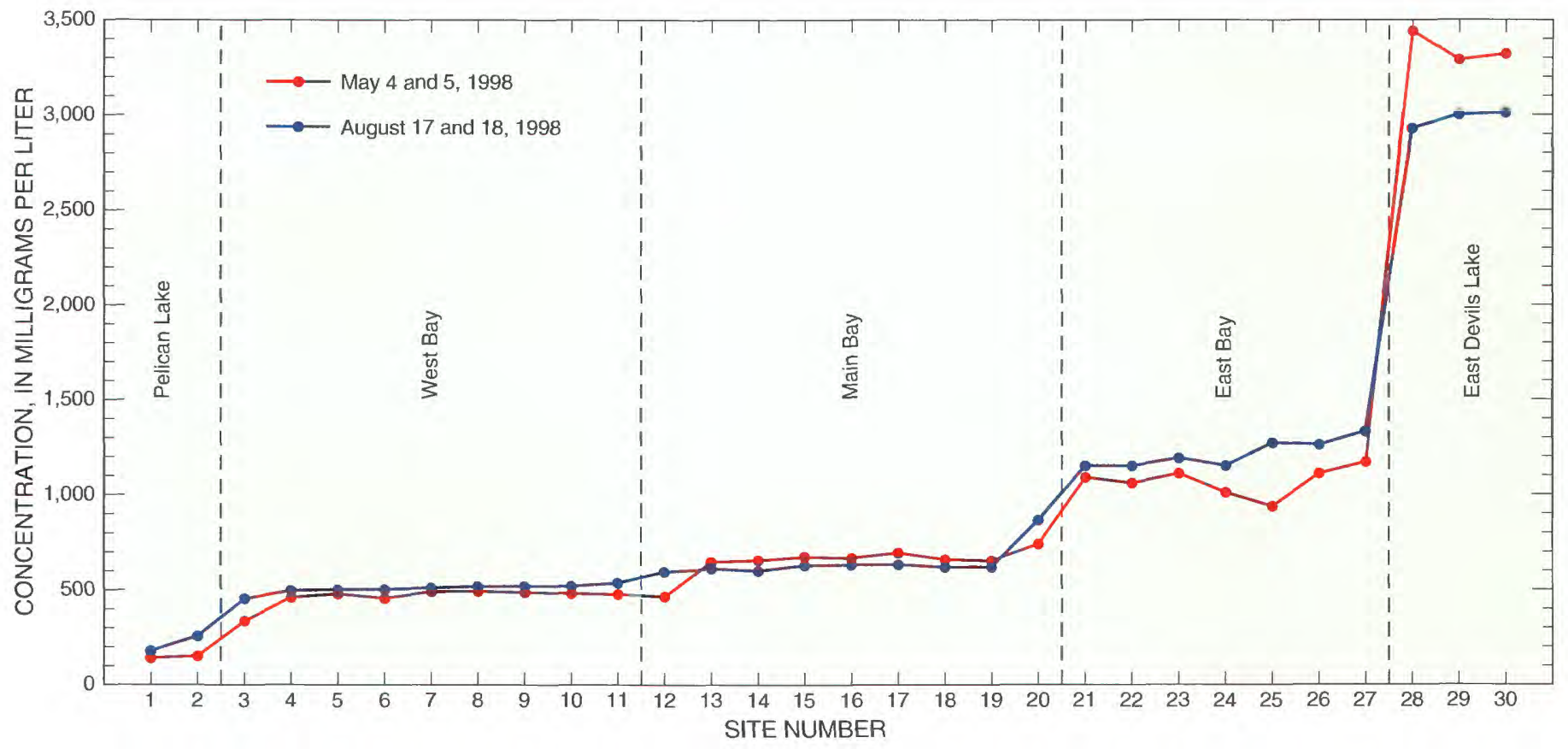

Figure 4. Dissolved-sulfate concentrations at spatial sample sites in Devils Lake.

sampling period. Apparently, the flux of sulfate from bed sediment and/or mixing with East Devils Lake were sufficient to counteract dilution from Main Bay, even during the spring lake-level rise.

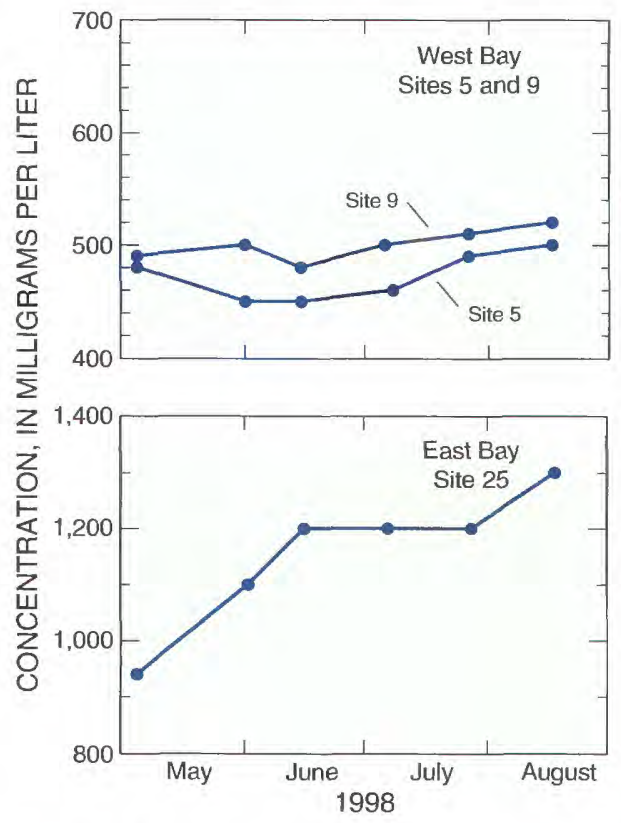

Dissolved-sulfate concentrations at site 29 in East Devils Lake decreased from $3,300 \mathrm{mg} / \mathrm{L}$ on May 5 to $2,900 \mathrm{mg} / \mathrm{L}$ on July 28 and then increased in August. Dilution from East Bay is the dominant
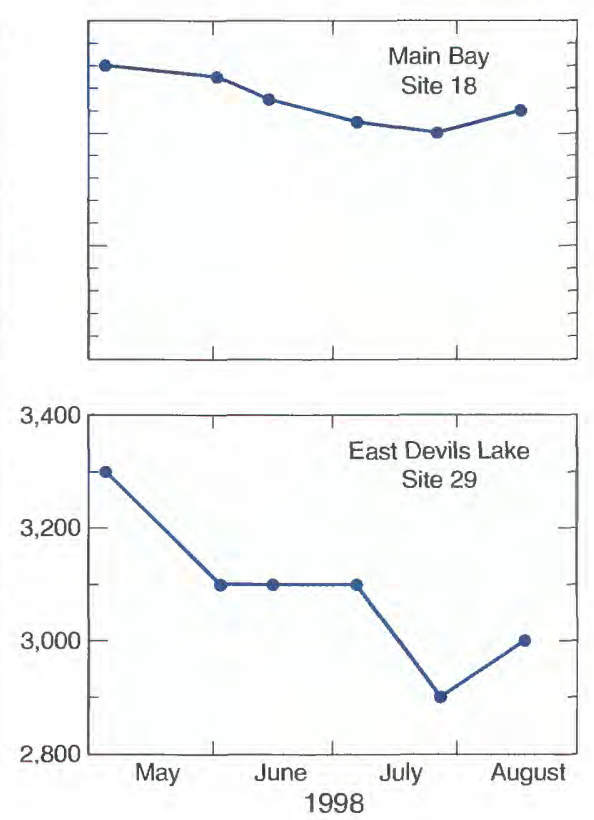

Figure 5. Dissolved-sulfate concentrations at selected temporal sample sites in West Bay, Main Bay, East Bay, and East Devils Lake.

factor affecting sulfate concentrations during the spring lake-level rise and well into the summer.

Additional information, including data for each of the constituents listed in table 1 , can be obtained by accessing the U.S. Geological Survey North Dakota Home Page on the World Wide Web at http://nd.water.usgs.gov.

-B. A. Sether, A. V. Vecchia, and W. R. Berkas

\section{References}

Wiche, G.J., 1998, Lake levels, streamflow, and surface-water quality in the Devils Lake area, North Dakota, through 1997: U.S. Geological Survey Fact Sheet FS-033-98, 4 p.

Williams-Sether, Tara, Lent, R.M., and Wiche, G.J., 1996, Variations in surfacewater quantity and quality as a result of the 1993 summer flood in the Devils Lake Basin, North Dakota: U.S. Geological Survey Water-Resuurces Investigations Report 96-4028, 32 p.

\section{For more information contact any of the following:}

For water information:

District Chief

821 East Interstate Avenue

Bismarck, ND 58501

(701) 250-7400
For more information on all USGS reports and products (including maps, images, and computerized data), call 1-800-USA-MAPS.
Additional earth science information can be found by accessing the USGS "Home Page" on the World Wide Web at "http://www.usgs.gov". 